\title{
Investigation of Preliminary Phytochemicals, Analgesic, Anti-Arthritic, Thrombolytic and Cytotoxic Activities of Begonia Roxburghii (Miq.) DC. Leaves
}

Hosne Mobarak ${ }^{1 a}$, Mohammed Sohel Meah ${ }^{1 a}$, Nahid Sikder ${ }^{1}$, Md. Tareq ${ }^{1}$, Afrina Azad ${ }^{1}$, Riniara Khatun ${ }^{1}$, Mst. Samima Nasrin ${ }^{1,2}$, Md. Obayed Raihan ${ }^{3}$, A.S.M. Ali Reza ${ }^{1,2^{*}}$

\footnotetext{
${ }^{1}$ Department of Pharmacy, International Islamic University Chittagong, Chittagong 4318, Bangladesh;

${ }^{2}$ Department of Biochemistry \& Molecular Biology, University of Chittagong, Chittagong 4331, Bangladesh;

${ }^{3}$ Department of Pharmacy, Jessore University of Science and Technology, Jessore 7408, Bangladesh.

${ }^{a}$ These authors are joint first author on this work.
}

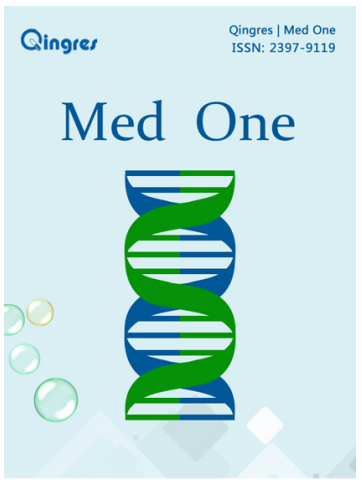

http://mo.qingres.com

\section{GOPEN ACCESS}

DOI: $10.20900 / \mathrm{mo} .20180001$

Received: January 22, 2018

Accepted: February 23, 2018

Published: February 25, 2018

Copyright: $\odot 2018$ Cain et al. This is an open access article distributed under the terms of the Creative Commons Attribution License, which permits unrestricted use, distribution, and reproduction in any medium, provided the original author and source are credited.
${ }^{*}$ Corresponding Author: A.S.M. Ali Reza, Assistant Professor, Department of Pharmacy, International Islamic University Chittagong, Kumira, Sitakunda, Chittagong-4318, Bangladesh. Tel: +88-031610085, Fax:+88-031-610307, E-mail: alirezaru@gmail.com, alireza@ pharm.iiuc.ac.bd.

\section{ABSTRACT}

Background: The study was designed to investigate the phytochemical , analgesic, anti-arthritic, thrombolytic and cytotoxic evaluation of the Begonia roxburghii (Miq.) DC leaves extract (nHBR) using both in vitro and in vivo methods.

Methods: The acetic acid induced writhing test and formalin induced pain test was used to perform anti-nociceptive activity on mice. In vitro anti-arthritic activity was assessed using protein denaturation method. The clot lysis activity was considered to evaluate thrombolytic potentials of the plant extract. The cytotoxic study was performed using brine shrimp larvae.

Results: The phytochemical study has shown the abundance of flavonoids, alkaloids, glycosides, tannins, saponins and reducing sugars in the plant extract. In acetic acid-induced writhing test, the extract at different doses $(100-400 \mathrm{mg} / \mathrm{kg})$ reduced the number of 
writhing by $26.42 \pm 1.13,43.64 \pm 2.50$ and 55.42 $\pm 1.83 \%$ respectively. The nHBR inhibited the licking response in both the early phase (56.52 \pm $2.55 \%)$ and the late phase $(62.52 \pm 2.57 \%)$ in the formalin induced pain test. Moreover, the results revealed concentration dependent anti-arthritic effect in protein denaturation method with maximum inhibition $69.61 \pm 2.15 \%$ at doses $1000 \mu \mathrm{g} / \mathrm{ml}$. The nHBR also showed $(47.77 \pm 1.80 \%)$ clot lytic activity and cytotoxicity with LC50 $67.61 \mu \mathrm{g} / \mathrm{ml}$ in the brine shrimp larvae bioassay.

Conclusion: The study demonstrated phytochemical , anti-nociceptive, anti-arthritic, clot lysis and cytotoxic activities of the Begonia roxburghii (Miq.) DC.

Keywords: Anti-nociceptive; Anti-arthritic; Thrombolytic; Cytotoxicity

\section{INTRODUCTION}

Nowadays, medicinal plants are considered as potential sources of new drugs. Scientists are screening medicinal plants to find out novel drugs against different diseases. In Bangladesh, the folk medicinal practitioners use medicinal plants directly as primary health care therapeutics ${ }^{[1,2]}$. The folk medication based on skill and plants with a history of traditional use should be tested using modern methods to find out novel therapeutics. Tissue damage is responsible for pain which is associated by unpleasant sensory and emotional experience ${ }^{[3,4]}$. Pain is also interfere our daily life activity and enhance absenteeism from work, underemployment and unemployment and results in a massive economical loss to the persons ${ }^{[5]}$. Nonsteroidal anti-inflammatory drugs are recommended for the management of mild to moderate pain, while steroidal and opioid drugs are used to mitigate acute and chronic pains. But several adverse effects of these drugs such as gastrointestinal disturbances, cardio vascular diseases, renal dysfunction, drug tolerance and drug dependence limit their free usages $^{[6,7]}$. Rheumatoid arthritis (RA) is a chronic inflammatory disorder characterized by ankle joint inflammation and formation of synovium, pannus leades to changes the morphology of the joint ${ }^{[8]}$. Although for the treatment of RA numerous drugs have been developed and used such as Nimesulide, Nimesulide, Abatacept but they are too expensive and have adverse effects ${ }^{[9]}$. The streptokinase, urokinase and tissue plasminogen activators are thrombolytic medication used for the emergency management of stroke and heart attack. But uses of this drug is linked with high risk of bleeding disorder and allergic problems ${ }^{[10,11]}$. Moreover, these drugs are contraindicated for the patients who have a history of nervous lesions, bleeding disorder and low blood pressure ${ }^{[10]}$. Therefore, the herbal medicines coup up the conventional medication due to their pharmacological activities, money making capability and less or no side effects in different cultures throughout the world ${ }^{[12]}$.

Begonia roxburghii (Miq.) DC. (B. roxburghii) belongs to Begoniaceae family. It is an annual herb and is distributed widely in the in shady moist places of India, Nepal, China and Bangladesh. In Bangladesh B. roxburghii is distributed widely in the marginal forests such as Chittagong, Cox's Bazar, Moulvibazar and Sylhet. The leaves and roots of B. roxburghii are widely used in the treatment of tongue abnormalities, diarrhea, dysentery and jaundice ${ }^{[13]}$. Moreover, fresh leave juice extract is directly consumed for management of diabetes ${ }^{[14]}$. Hence, the objective of this study was to assess the preliminary phytochemicals, analgesic, anti-arthritic, thrombolytic and cytotoxic properties of B. roxburghii.

\section{MATERIALS AND METHODS}

\subsection{Chemicals}

Sodium citrate, sodium phosphate, albumin and diclofenac sodium were purchased from Merck (Mumbai, India) through Taj Scientific Ltd. Bangladesh. Commercially available lyophilized Streptokinase (SK) vial (Durakinase, Dongkook Pharma. Co. Ltd, South Korea) was procured from local market. Acetic acid, Vincristine sulfate were purchased from Sigma-Aldrich (Taufkirchen, Germany). Analytical grade n-hexane was procured from local suppliers and distilled to purify for experiments.

\subsection{Plant materials}

Fresh leaves of Begonia roxburghii (Miq.) DC. were collected from the hill track area of Shitakunda, Chittagong, Bangladesh (March 2016) and plant sample was identified by an expert taxonomist Dr. Sheikh Bokhtear Uddin who is working in the Department of Botany of University of Chittagong. A voucher specimen (accession No. 23164) has been preserved in the aforementioned department.

\subsection{Preparation of crude extract}


The collected leaves were cleaned, shade-dried and finally in a mechanical drier (Ecocell, MMM Group, Germany). The dried samples were powdered (700 g) to extract with $\mathrm{n}$-hexane $(1000 \mathrm{ml})$.

The powdered material placed into an amber bottle for a 7-days-exhaustive extraction with occasional stirring and shaking. The extracts were filtered and concentrated under reduced pressure using rotary evaporator (RE200, Bibby sterling Ltd, UK) to have a black-green semisolid of about $28.5 \mathrm{~g}$.

\subsection{Experimental animals}

Swiss Albino mice weighing $35-40 \mathrm{~g}$ of both male and female were collected from International Center for Diarrheal Diseases Research, Bangladesh (ICDDRB) and housed in polypropylene cages under controlled conditions. The animals were exposed to alternative 12:12 $\mathrm{h}$ light and dark cycle at an ambient temperature of $26 \pm 2^{\circ} \mathrm{C}$. Animals were allowed free access to drinking water and pellet diet, collected from ICDDRB, Dhaka. Mice were acclimatized for seven days in the laboratory environment prior to the study. The set of rules followed for animal experiment were approved by the institutional animal ethics committee, Department of Pharmacy, International Islamic University Chittagong, Bangladesh according to governmental guidelines ${ }^{[15]}$.

\subsection{Phytochemical screening}

The qualitative phytochemical screening was performed by standard procedures ${ }^{[16]}$ and the results revealed presence or absence of secondary plant metabolites such as alkaloids, flavonoids, tannins, saponins, phenol, carbohydrate, glycoside.

\subsection{Antinociceptive activity}

\subsubsection{Acetic acid-induced writhing test}

Either sex of mice $(n=5)$ weighing $35-40 \mathrm{~g}$ was used and divided into 5 groups. Normal control group received normal saline (10 ml/kgbw), reference control group received standard drug diclofenac sodium (10 $\mathrm{mg} / \mathrm{kgbw}$ ) while the rest of the groups were injected intraperitoneally with 100 , 200 , and $400 \mathrm{mg} / \mathrm{kgbw}$ of nHBR. After $30 \mathrm{~min}$ of administration, the animals were injected (i.p.) $1 \%$ $(\mathrm{v} / \mathrm{v})(10 \mathrm{ml} / \mathrm{kgbw})$ acetic acid. After $5 \mathrm{~min}$ of acetic acid injection, abdominal constrictions were counted for $10 \mathrm{~min}$ and the responses were compared with control group ${ }^{[17,18]}$. Antinociceptive activity was calculated as the writhing percentage of inhibition. The percentage of inhibition was calculated using the following ratio:
Writhing inhibition $=\frac{\text { Mean no. of writhing(control) }- \text { Mean no. of writhing(test) }}{\text { Mean number of writhing }(\text { control })} \times 100$

\subsubsection{Formalin-induced pain test}

This biphasic method employed in mice model was assessed as described previously by Hunskaar and Hole ${ }^{[19]}$. Formalin solution $(2.5 \%, 20 \mu \mathrm{l})$ prepared by $0.9 \%$ saline solution was injected into the subplantar region of the right hind paw of mice. Animals were pretreated intraperitoneally with vehicle $(0.1 \mathrm{ml} /$ $\mathrm{kg}$ saline solution), diclofenac sodium (10 mg/kg) and different doses of extract $(100,200$ and $400 \mathrm{mg} / \mathrm{kg}$ ) $1 \mathrm{~h}$ prior to formalin injection. Responses measured for $5 \mathrm{~min}$ is considered as first phase and 15-30 min is considered as second phase after formalin injection. First phase and second phase response corresponds to the neurogenic and inflammatory pain responses, respectively. Antinociceptive activity was calculated as the percentage inhibition of licking time.

$(\%)$ of inhibition $=\frac{\text { Mean of licking time }(\text { control })-\text { Mean of licking time(test) }}{\text { Mean of licking time }(\text { control })} \times 100$

\subsection{In vitro anti-arthritic activity}

\subsubsection{Inhibition of protein denaturation method}

Anti-arthritic activity of the extracts was determined using the protein denaturation method ${ }^{[20]}$. The constituents of reaction solution were $100 \mu \mathrm{nHBR}$ (final concentration $125-1000 \mu \mathrm{g} / \mathrm{ml}$ ) and $100 \mu \mathrm{l}$ of $5 \%$ aqueous bovine serum albumin then the $\mathrm{pH}$ was adjusted using glacial acetic acid. The samples were incubated at $37^{\circ} \mathrm{C}$ for $20 \mathrm{~min}$ and then heated to $70^{\circ} \mathrm{C}$ for $10 \mathrm{~min}$. After incubation the mixture was allowed to cool for 10 min and a turbid solution was found. Then the turbidity was measured at $660 \mathrm{~nm}$. The blank consist of the sample and distilled water. Distilled water was used as the negative control. The positive control was diclofenac sodium. Percentage inhibition was calculated using the formula:

$\%$ of protein denaturation $=\frac{\text { Aabsorbance of control }- \text { Absorbance of test sample }}{\text { Absorbance of test control }} \times 100$

\subsection{Thrombolytic activity}

The clot lysis activity were performed as described earlier ${ }^{[21]}$. A $3 \mathrm{ml}$ venous blood drawn from the healthy volunteers was distributed in nine different 
pre-weighed sterile microcentrifuge tube $(0.5 \mathrm{ml} /$ tube) and incubated at $37^{\circ} \mathrm{C}$ for $45 \mathrm{~min}$. After clot formation, the developed serum was removed without disturbing the clot and each tube having clot was again weighed to determine the clot weight (clot weight $=$ weight of clot containing tube - weight of tube alone). The plant extracts was added to each microcentrifuge tube separately containing pre-weighed clot. As a positive control, $100 \mu \mathrm{l}$ of streptokinase (SK) and as a negative non-thrombolytic control, $100 \mu$ l of distilled water were separately added to the control tubes. All the tubes were then incubated at $37^{\circ} \mathrm{C}$ for 90 min and observed for clot lysis. After incubation, fluid released was discarded and tubes were again weighed. Difference obtained in weight taken before and after clot lysis was expressed as percentage of clot lysis. The experiment was repeated with the blood samples of the 10 volunteers without a history of oral contraceptive or anticoagulant therapy since two weeks.

\subsection{Brine shrimp cytotoxicity}

\subsubsection{Assay procedure}

The experiment was carried out with the method as reported earlier ${ }^{[22]}$. The crude $\mathrm{nHBR}$ was dissolved in DMSO to obtain a solution of $5 \mathrm{mg} / \mathrm{ml}$ which was subjected to serial dilution getting concentrations between 20 to $100 \mu \mathrm{g} / \mathrm{ml}$. A $5.0 \mathrm{ml}$ of artificial sea water was added to all the test tubes. Then 10 shrimps transported into each vial and incubated for $24 \mathrm{~h}$ under light at room temperature $\left(25-29^{\circ} \mathrm{C}\right)$ and the survivors were counted with the help of a magnifying glass. Experiments were conducted in a set of three tubes per dose along with vincristine sulfate. The lethal concentration (LC50) that would kill one half of the nauplii was determined from a linear regression equation.

\subsubsection{Statistical analysis}

The data was analyzed by one-way ANOVA followed by Dunnet's test to estimate significant differences between the test and control groups with GraphPad Prism Data Editor for Windows, Version 5.0 (GraphPad Software Inc., San Diego, CA). Values were expressed as a mean \pm standard error of mean ( \pm SEM). $p$ values $(<0.05-<0.01)$ were considered as statistically significant.

\section{RESULTS}

\subsection{Phytochemical Screening}

The qualitative phytochemical analysis conducted on nHBR extract revealed the presence of medicinally active different types of secondary metabolites, namely carbohydrates, alkaloids, flavonoids, glycosides, tannins, saponins while absence of steroids and terpenoids (Table 1).

Table 1. Qualitative phytochemical screening of Begonia roxburghii leaves extract

\begin{tabular}{|c|c|c|c|}
\hline Phytochemical Class & Test performed & Observations & Results \\
\hline Alkaloids & Dragendorff's Test & Turbidity/precipitation & + \\
\hline Carbohydrates & Molisch Test & $\begin{array}{l}\text { Formation of a purple product at the } \\
\text { interface of the two layers }\end{array}$ & + \\
\hline Flavonoid & Ferric chloride test & $\begin{array}{l}\text { Formation of yellow color which } \\
\text { changed to colorless on acid addition }\end{array}$ & +++ \\
\hline Steroids & Liebermann Burchard test & Green to pink color was absent & - \\
\hline Terpenoids & Liebermann Burchard test & $\begin{array}{l}\text { Appearance of reddish brown-deep } \\
\text { red color }\end{array}$ & - \\
\hline Glycosides & Keller Killanic test & $\begin{array}{l}\text { Lower reddish brown layer \& upper } \\
\text { acetic acid layer which turns bluish } \\
\text { green }\end{array}$ & + \\
\hline Tannins & Gelatin Test & Appearance of white precipitate & ++ \\
\hline Saponins & Froth Test & Stable froth formation & + \\
\hline
\end{tabular}

Bioavailability Key: $(-)=$ not present; $(+)=$ present in low concentration; $(++)=$ present in moderately high concentration; $(+++)=$ present in very high concentration. 


\subsection{Antinociceptive activity}

\subsubsection{Acetic acid induced writhing test}

Data for acetic acid-induced writhing test in mice are shown in Fig.1. The positive control group caused the minimum reduction of the number of writhing $(18.05 \pm 1.51)$ and showed the maximum inhibition of $68.33 \pm 1.10 \%$ at dose $10 \mathrm{mg} / \mathrm{kg}$. The $\mathrm{nHBR}$ was able to inhibit writhing significantly while compared to the control group $(p<0.01)$. Mention that, the test control group showed number of writhing 26.38 $\pm 2.15,33.78 \pm 1.19$ and $22.30 \pm 1.12$ at doses 100 , 200 and $400 \mathrm{mg} / \mathrm{kg}$ respectively. The percentages of inhibition of constrictions were calculated as $26.42 \pm$ $1.13,43.64 \pm 2.50$ and $55.42 \pm 1.83 \%$ for $n$ HBR of doses of 100,200 and $400 \mathrm{mg} / \mathrm{kg}$ respectively.
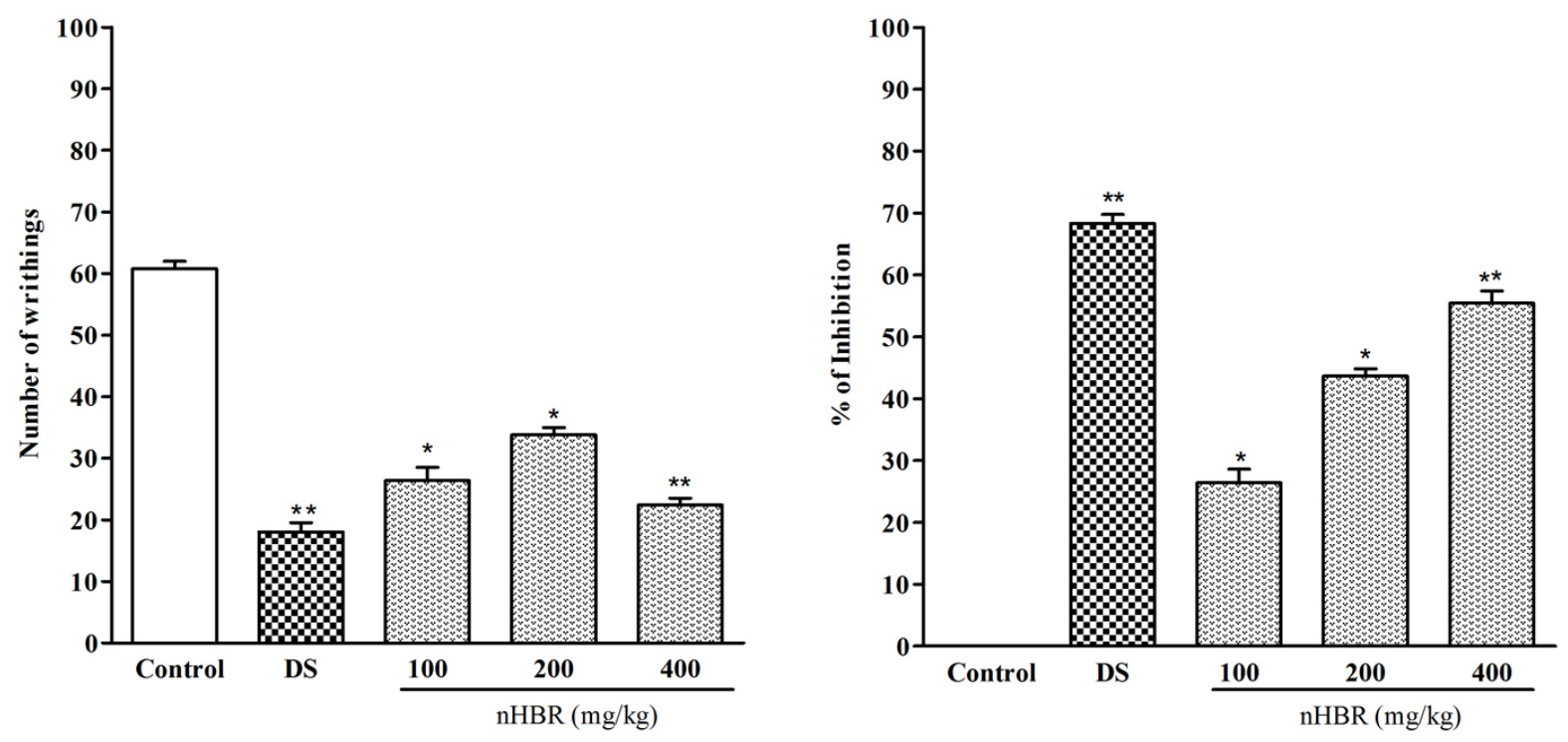

Fig. 1 Effect of $\mathrm{n}$-hexane extract of the Begonia roxburghii and DS (10 $\mathrm{mg} / \mathrm{kg})$ on acetic acid induced writhing test. Values are mean \pm S.E.M. ${ }^{*} p<0.05$ and ${ }^{* *} p<0.01$, significantly different from control; ANOVA followed Dunnett's test ( $n=5$, per group). DS: diclofenac sodium, nHBR, Begonia roxburghii leaves extract.

\subsubsection{Formalin induced pain test}

The characteristics biphasic nociceptive responses of $\mathrm{nHBR}$ are presented in Fig. 2. The nHBR produced a dose-dependent inhibition of nociception both neurogenic (0-5 $\mathrm{min})$ and inflammatory (15-30 min) phases at the doses of 100,200 and $400 \mathrm{mg} /$ $\mathrm{kg}$. The maximum inhibition of $62.52 \pm 2.57 \%$ was obtained at $400 \mathrm{mg} / \mathrm{kg}$ i.p in the late phase of the formalin test. Whereas, in the early phase of licking the highest inhibition was $56.52 \pm 2.55 \%$ i.p at 400 $\mathrm{mg} / \mathrm{kg}$ which is significant compared to the positive control group (73.52 $\pm 3.25 \%)$ at dose $10 \mathrm{mg} / \mathrm{kg}$. 

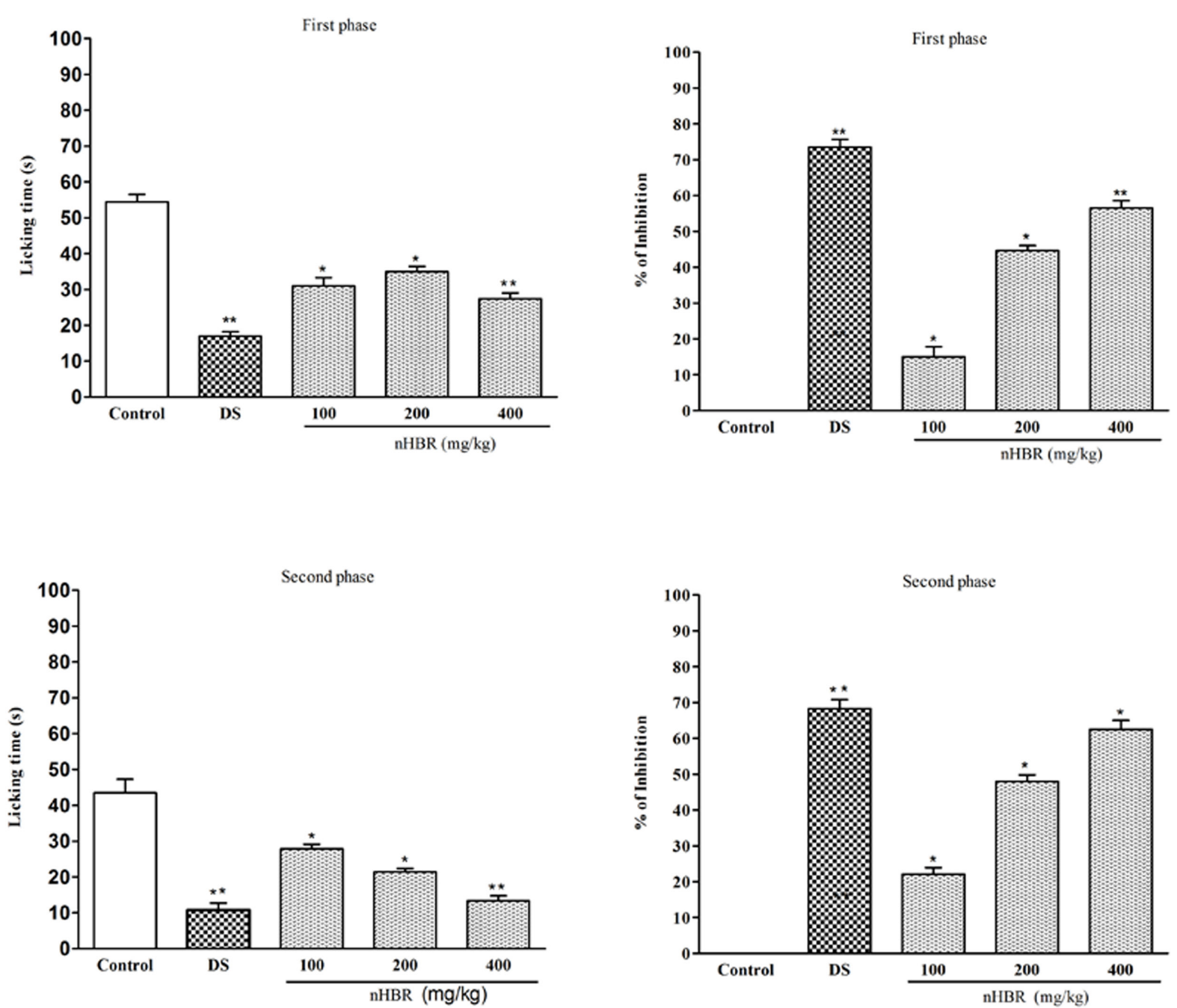

Fig. 2 Effect of $\mathrm{n}$-hexane extract of the Begonia roxburghii and DS (10 mg/kg) on formalin test (first phase and second phase). Values are mean \pm S.E.M. ${ }^{*} p<0.05$ and ${ }^{* *} p<0.01$, significantly different from control; ANOVA followed Dunnett's test ( $n=5$, per group). DS: diclofenac sodium, nHBR, Begonia roxburghii leaves extract.

\subsection{In vitro anti-arthritic activity}

The anti-arthritic activity was performed using bovine serum albumin (BSA). The results demonstrated the significant $(p<0.05)$ inhibition of protein denaturation of $\mathrm{nHBR}$ as shown in Fig.3. The anti-arthritic activities were increased with the dose in a noteworthy manner. The crude extracts demonstrated $40.70 \pm 2.50,50.54 \pm 3.75,64.37$ \pm 1.85 and $69.61 \pm 2.15 \%$ inhibition of protein denaturation at $125,250,500$ and $1000 \mu \mathrm{g} / \mathrm{ml}$ respectively, whereas the reference drug diclofenac sodium showed maximum $83.50 \pm 3.25 \%$ inhibition at a dose of $1000 \mu \mathrm{g} / \mathrm{ml}$. 


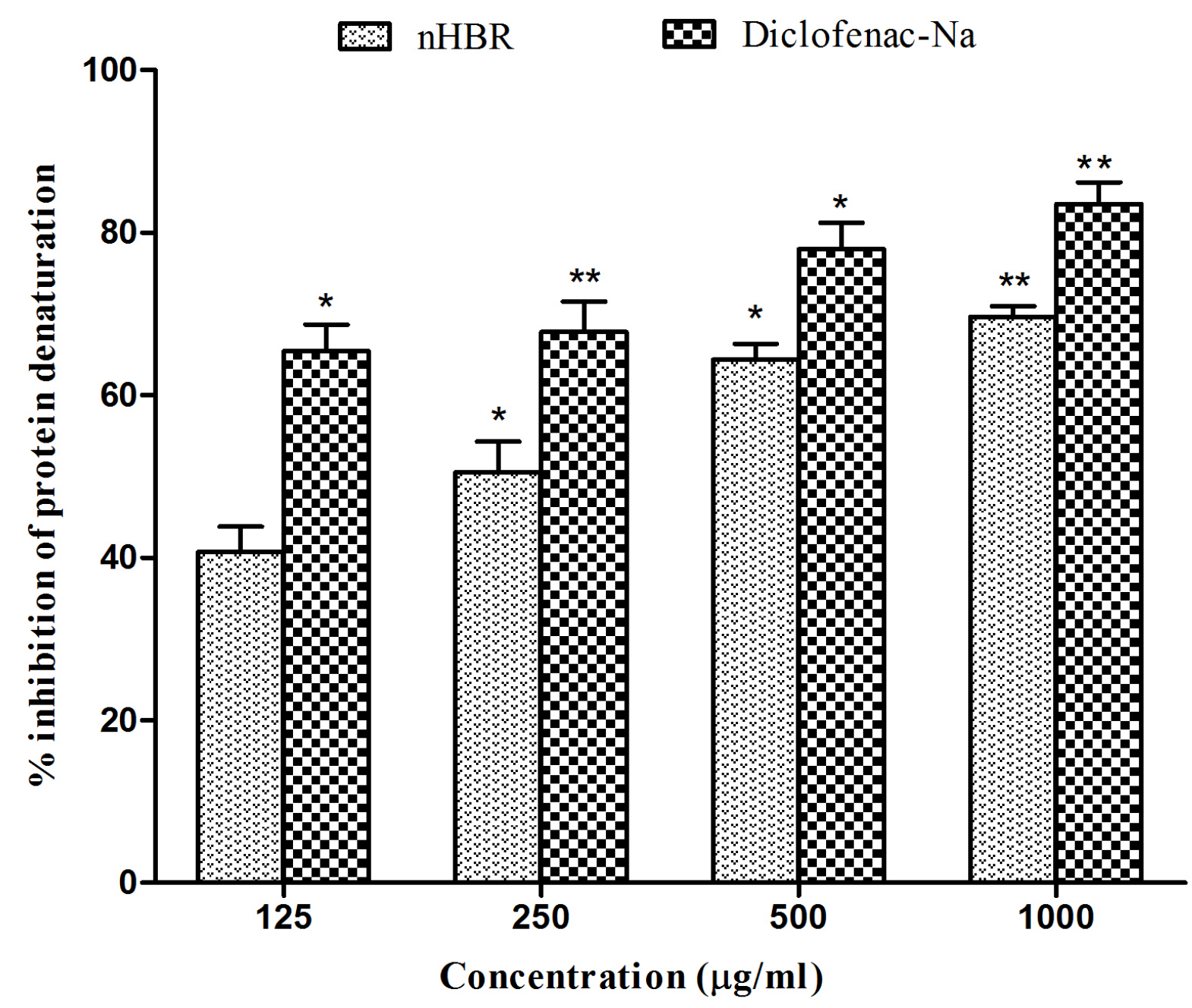

Fig. 3 Effect of $n$-hexane extract of the Begonia roxburghii against protein denaturation using bovine serum albumin. All the values are expressed as mean $\pm \operatorname{SEM}(n=3){ }^{* *}=p<0.01,{ }^{*}=p<0.05$ vs Diclofenac-Na, nHBR, Begonia roxburghii leaves extract

\subsection{Thrombolytic Activity}

The results of the thrombolytic test are shown in Fig. 4. The nHBR had a significant clot lysis effect when after addition of $100 \mu \mathrm{l} \mathrm{SK}$, a positive control $(30,000$ I.U.) to the clots along with 90 minutes of incubation at $37^{\circ} \mathrm{C}$, provided $73.13 \pm 2.80 \%$ clot lysis. On the other hand, sterile distilled water was treated as negative control which showed only $9.66 \pm 1.20$ $\%$, a negligible clot lysis. Clots when treated with $100 \mu \mathrm{l}$ of $\mathrm{nHBR}$ exhibited $47.77 \pm 1.80 \%$ clot lysis comparing with the positive control the mean clot lysis percentage difference was significant $(p<0.05)$. 


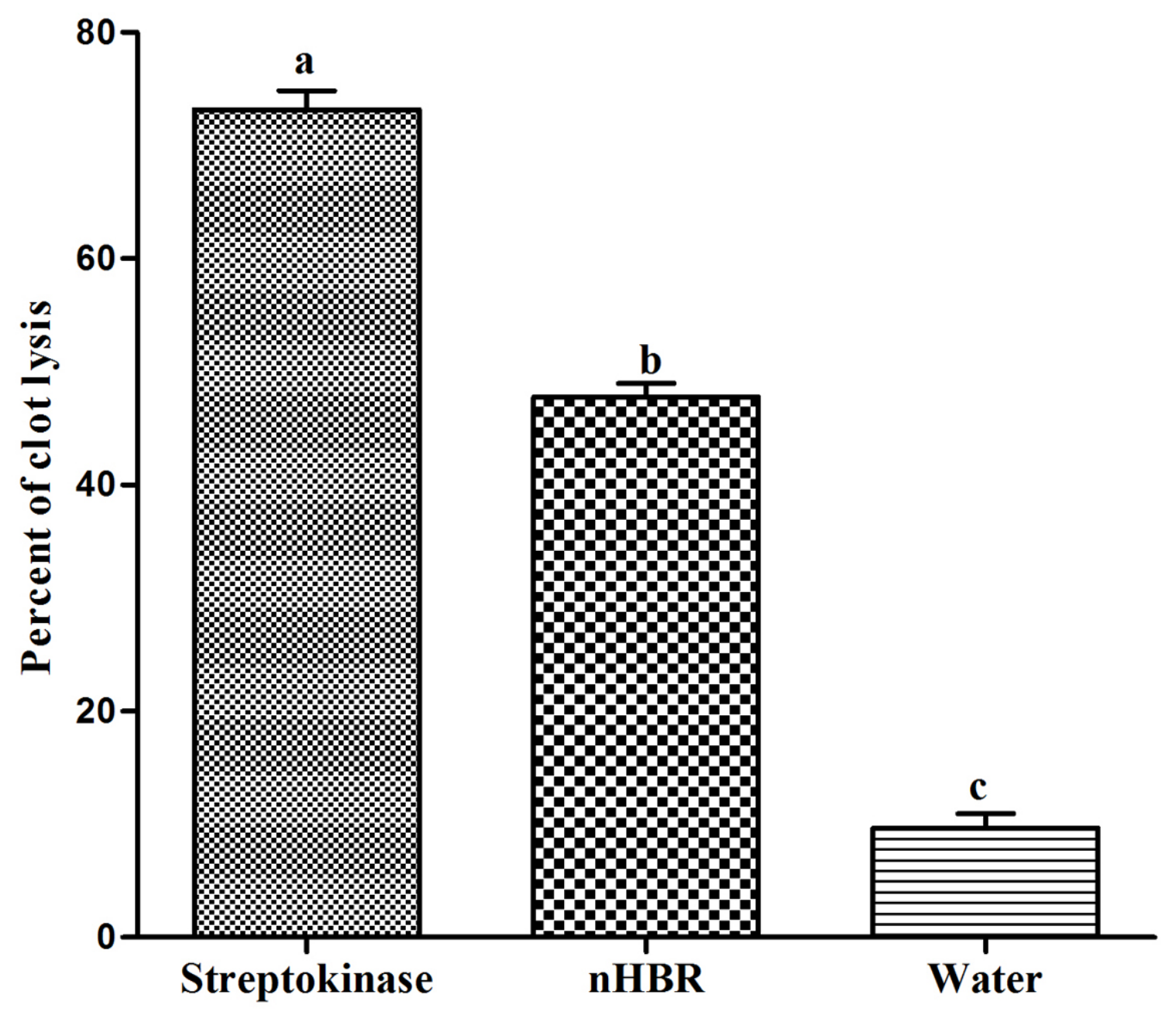

Fig. 4 Clot lysis by streptokinase, nHBR and water in vitro. Values are expressed as mean \pm SEM. $p<0.05$, significantly different from control; ANOVA followed by Dunnett's test. nHBR, Begonia roxburghii leaves extract.

\subsection{Cytotoxicity screening}

\subsubsection{Brine shrimp lethality bioassay}

The lethality of the nHBR was determined on a simple zoological organism (Artemia salina). The results from screening of $\mathrm{nHBR}$ against Artemia salina larvae are shown in Fig. 5. The degree of lethality was found to be directly proportional to the concentration of test extracts, which provided linearity in the dose-effect relationship and determination of the LC50 value. In this assay, nHBR exhibited an LC50 value of $67.61 \mu \mathrm{g} / \mathrm{mL}$, which was significantly $(p<0.05)$ different in reference to positive control vincristine sulfate $(50.11 \mu \mathrm{g} / \mathrm{mL})$, indicating the lower toxicity of the tested extract. 


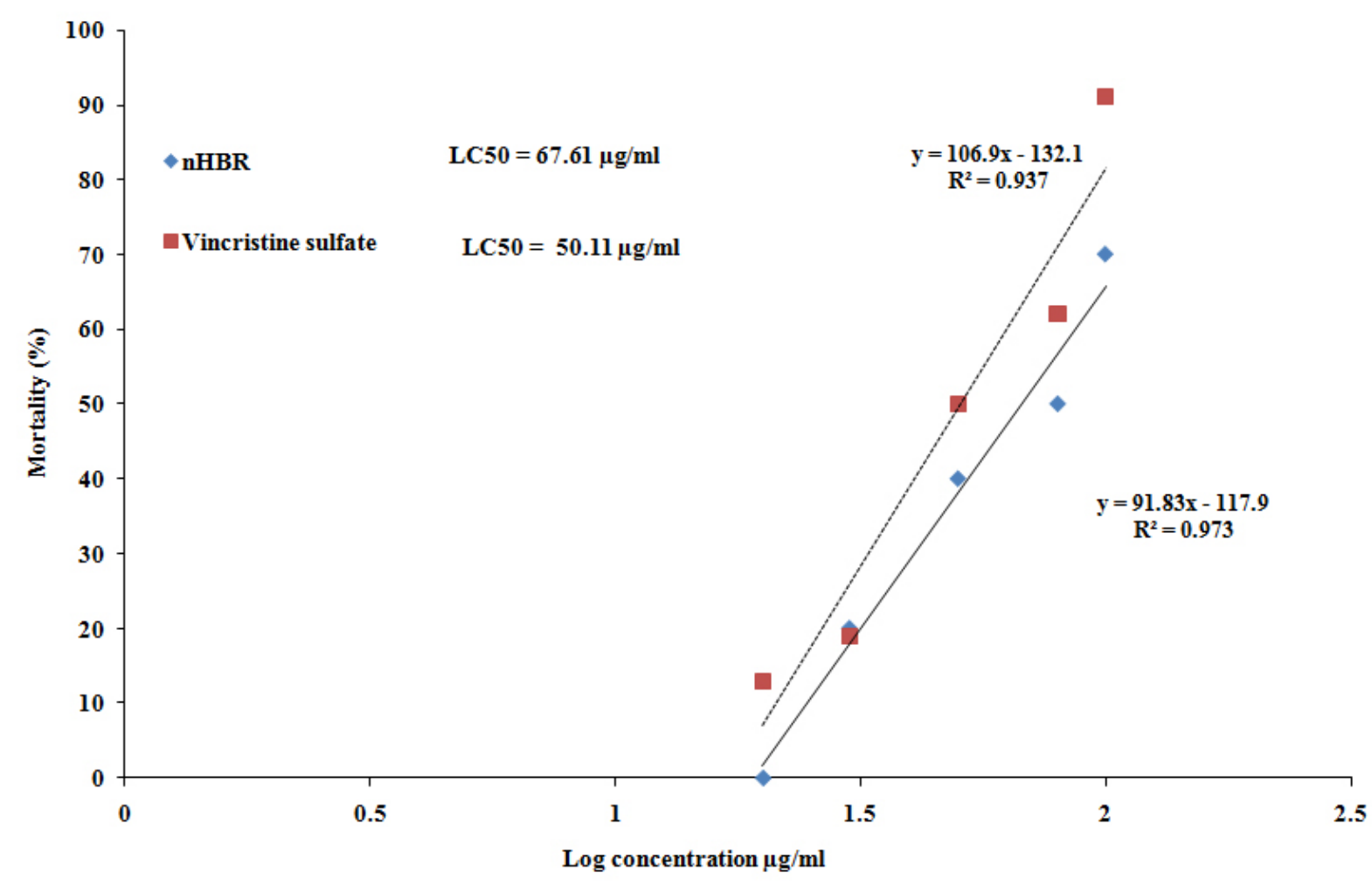

Fig. 5 Cytotoxic effects of $\mathbf{n}$-hexane extract of the Begonia roxburghii. Comparative mortality rate of various concentrations of both $\mathrm{nHBR}$ and reference cytotoxic agent Vincristine sulfate through regression analysis. $\mathrm{nHBR}$, Begonia roxburghii leaves extract

\section{DISCUSSION}

Biological activities of medicinal plants are not only useful for cultural traditions and biodiversity but also for development of new drugs ${ }^{[23]}$. Medicinal plants are the major resource of bioactive secondary metabolites which is differs from one plants to another plants. The bioactive secondary plant metabolites acts as a part of integrated health care system because of their therapeutic role in prevention of chronic and degenerative diseases ${ }^{[24,}$ 25].

Acetic acid-induced writhing test evaluated the antinociceptive activity of nHBR characterizing through abdominal contractions, movements of the body as a whole and twisting of the dorso-abdominal muscles. In this method, the acetic acid helps to induce the release of inflammatory mediators such as bradykinin and serotonin, which stimulate the nociceptive neurons ${ }^{[26,27]}$. The intraperitoneal administration of nHBR remarkably reduced the writhing induced by acetic acid. The formalin test is one of the widely used methods of expressing pain and analgesic mechanism in contrast to mechanical or thermal stimulus methods ${ }^{[28]}$. In this test the nHBR has shown the ability to affect both the early and late phase inflammatory effects. Mention that, capability of acting both phase implies the involvement of central and peripheral pain relief activity of the extract. The early phase demonstrates as neurogenic pain, an acute response observed immediately after the administration of formalin due to direct stimulation of nociceptive neurons. While the late phase gives a delayed response made by the release of inflammatory mediators especially prostaglandins, histamine, serotoninand bradykinin, and activation ofthe neurons in the dorsal horns of the spinal cord ${ }^{[29]}$. The early and late phases have used to characterize the analgesic potentials as well as to explain the mechanisms of antinociception. It has been reported that the narcotics or opioid 
analgesics exert its antinociceptive effects for both phases while the first phase is more sensitive whereas NSAIDs seem to suppress only the second phase ${ }^{[30]}$. Therefore the administration of nHBR in different doses significantly inhibited the pain response in both phases as confirmed by reduced licking behavior. This biphasic reducing liking behavior is an indicator of neurogenic and inflammatory pain modulators.

The bovine serum albumin (BSA) is used to evaluate anti-arthritis activity of nHBR and BSA is heated and it undergoes denaturation ${ }^{[20]}$. Moreover, the denaturation of protein is one of the reasons of rheumatoid arthritis. The mechanism of denaturation probably involves alteration of electrostatic, hydrogen, hydrophobic and disulphide bonds ${ }^{[31]}$. The productions of auto antigen are associated with type-III hypersensitivity reaction and responsible for several diseases such as serum sickness, glomerulonephritis, rheumatoid arthritis and systemic lupus erythematosus ${ }^{[32]}$. The nHBR showed dose dependent inhibition of protein denaturation. The promising activities of $\mathrm{B}$. roxburghii leave extracts are due to the capability of controlling the production of auto antigen and thereby it inhibits the denaturation of protein.

The development of thrombus is the results of imbalance activity between thrombogenic factors and protective mechanisms, which is accelerated several vascular diseases including stroke, myocardial infarction, deep vein thrombosis, portal vein thrombosis, renal vein thrombosis ${ }^{[33]}$. In this study, the extract showed significant $(p<0.05)$ thrombolytic activity comparing with standard drug streptokinase. It has been reported that, presence of secondary plant metabolites like flavonoids might have the capability of clot lysis ${ }^{[34]}$. The preliminary phytochemical screening of this study showed that the nHBR contain abundance of flavonoids and the presence of plenty of flavonoids might be the one of the causes of thrombolytic activity.

The toxicity of medicinal plant is the prime concern to the practitioners ${ }^{[35]}$ and hence cytotoxic screening was carried out using brine shrimp assay to determine the preliminary toxicity data of the plant extract. Moreover, researchers showed a good correlation $(r=0.85 ; p<0.05)$ between the LC50 of the brine shrimp lethality test and the acute oral toxicity assay in mice ${ }^{[36]}$. Lagarto showed that, the LC50 < $10 \mu \mathrm{g} / \mathrm{ml}$ (LD50 between 100 and $1000 \mathrm{mg} /$ $\mathrm{kg}$ ) is considered as the cutoff value of cytotoxicity ${ }^{[36]}$. Based on the above correlation the $\mathrm{B}$. roxburghii leave showed lower toxicity (LC50 $=67.61 \mu \mathrm{g} / \mathrm{mL}$ ) and to be possessed for the production of analgesic, anti-arthritic and thrombolytic drugs.

\section{CONCLUSION}

The results of this study discovered that, the extract significantly showed both peripheral and central analgesic activity in established in vivo models. Then, the results obtained in this study may rationalize the potential anti-arthritic and thrombolytic activity with lower toxicity. The study corroborates traditional claims of the use of this medicinal plant in the management of pain, arthritis and thrombosis. Further work will ascertain the molecular structures and the specific pharmacology of the active principles.

\section{CONFLICT OF INTEREST}

The authors declare that they have no competing interests.

\section{AUTHORS' CONTRIBUTION}

HM, SK and NS carried out the experiments. MT, AA and RK wrote the manuscript. ASMAR and MSN supervised the work and prepared the manuscript. MOR contributed to the manuscript corrections. All authors read and approved the final manuscript.

\section{ACKNOWLEDGEMENT}

We are grateful to the Department of Pharmacy, International Islamic University Chittagong, Bangladesh, for providing facilities for this research work.

\section{REFERENCES}

1. Ansari $P$, Uddin MJ, Rahman MM, Abdullah-AlMamun M, Islam MR, Ali MH, Reza AS. Antiinflammatory, anti-diarrheal, thrombolytic and cytotoxic activities of an ornamental medicinal plant: Persicaria orientalis. J Basic Clin Physiol Pharmacol. 2017; 28(1): 51-58. 
2. Hossain MS, Reza AA, Rahaman MM, Nasrin MS, Rahat MRU, Islam MR, Uddin MJ, Rahman MA: Evaluation of morning glory (Jacquemontia tamnifolia (L.) Griseb) leaves for antioxidant, antinociceptive, anticoagulant and cytotoxic activities. J Basic Clin Physiol Pharmacol 2018; pii: /j/jbcpp.ahead-of-print/jbcpp-2017-0042/ jbcpp-2017-0042.xml. [Epub ahead of print]

3. Fordyce WE. Back pain in the workplace: management of disability in nonspecific conditions: a report of the task force on pain in the workplace of the International Association for the Study of Pain. IASP Press. 1995.

4. Bellah S, Islam M, Karim M, Rahaman M, Nasrin M, Rahman M, Reza A. Evaluation of cytotoxic, analgesic, antidiarrheal and phytochemical properties of Hygrophila spinosa (T. Anders) whole plant. J Basic Clin Physiol Pharmacol. 2017; 28(2): 185-190.

5. Baigi K, Stewart WF. Headache and migraine: a leading cause of absenteeism. Handb Clin Neurol. 2015; 131: 447-463.

6. Grosser T, Smyth E, FitzGerald GA. Antiinflammatory, antipyretic, and analgesic agents; pharmacotherapy of gout. Goodman and Gilman's the pharmacological basis of therapeutics. Brunton L, Chabner B, Knollman B, editor. New York: McGraw-Hill Medical. 2011; 12: 959-1004.

7. Yaksh TL, Wallace MS. Opioids, analgesia, and pain management. Goodman and Gilman's The Pharmacological Basis of Therapeutics. Brunton L, Chabner B, Knollman B, editor. New York: McGraw-Hill Medical. 2011: 12: 481-526.

8. Butler SH, Godefroy F, Besson J-M, WeilFugazza J. A limited arthritic model for chronic pain studies in the rat. Pain. 1992; 48(1): 73-81.

9. Chen Y, Wang QW, Zuo J, Chen JW, Li X. Antiarthritic activity of ethanol extract of Claoxylon indicum on Freund's complete adjuvant-induced arthritis in mice. BMC Complement Altern Med. 2017; 17(1): 11.

10. Naderi GA, Asgary S, Jafarian A, Askari N, Behagh A, Aghdam RH. Fibrinolytic effects of Ginkgo biloba extract. Exp Clin Cardiol. 2005; 10(2): 85.

11. Islam MR, Reza AA, Hossain MS, Farhana MK. In vitro Evaluation of Cytotoxic and Thrombolytic Activities of Oroxylum indicum (Linn.). Bangladesh Pharmaceutical Sociaty. 2015; 17(1): 70-74.
12. Rahman MA, Sultana $R$, Emran TB, Islam MS, Rahman MA, Chakma JS, Rashid HU, Hasan CM. Effects of organic extracts of six Bangladeshi plants on in vitro thrombolysis and cytotoxicity. BMC Complement Altern Med. 2013; 13(1): 25.

13. Rahman M. Diversity, ecology and ethnobotany of the Zingiberaceae of Bangladesh. J Econ Taxon Bot Addl Series. 1996; 12: 13-19.

14. Tag $H$, Kalita $P$, Dwivedi $P$, Das A, Namsa ND. Herbal medicines used in the treatment of diabetes mellitus in Arunachal Himalaya, northeast, India. J Ethnopharmacol. 2012; 141(3): 786-795.

15. Zimmermann M. Ethical guidelines for investigations of experimental pain in conscious animals. Pain. 1983; 16(2): 109-110.

16. Tiwari P, Kumar B, Kaur M, Kaur G, Kaur H. Phytochemical screening and extraction: a review. Int Pharm Sci. 2011; 1(1): 98-106.

17. Hendershot L, Forsaith J. Antagonism of the frequency of phenylquinone-induced writhing in the mouse by weak analgesics and nonanalgesics. J Pharmacol Exp Ther. 1959; 125(3): 237-240.

18. Koster R. Acetic acid for analgesic screening. In: Fed Proc. 1959; 1959: 412.

19. Hunskaar S, Hole K. The formalin test in mice: dissociation between inflammatory and noninflammatory pain. Pain. 1987; 30(1): 103-114.

20. Sakat S, Juvekar AR, Gambhire MN. In vitro antioxidant and anti-inflammatory activity of methanol extract of Oxalis corniculata Linn. Int $\mathrm{J}$ Pharm Pharm Sci. 2010; 2(1): 146-155.

21. Prasad S, Kashyap RS, Deopujari JY, Purohit HJ, Taori GM, Daginawala HF. Development of an in vitro model to study clot lysis activity of thrombolytic drugs. Throm J. 2006; 4(1): 14.

22. Meyer B, Ferrigni N, Putnam J, Jacobsen L, Nichols Dj, McLaughlin JL. Brine shrimp: a convenient general bioassay for active plant constituents. Planta Med. 1982; 45(05): 31-34.

23. Bhowmick R, Sarwar MS, RahmanDewan SM, Das A, Das B, NasirUddin MM, Islam MS, Islam MS. in vivo analgesic, antipyretic, and antiinflammatory potential in Swiss albino mice and in vitro thrombolytic activity of hydroalcoholic extract from Litsea glutinosa leaves. Biol Res. 2014; 47(1):56. 
24. Sahreen S, Khan MR, Khan RA. Valuation of antioxidant activities of various solvent extracts of Carissa opaca fruits. Food Chem. 2010; 122(4): 1205-1211.

25. Islam MR, Reza AA, Chawdhury KAA, Uddin $M$, Farhana M. Evaluation of in vitro antioxidant activity and cytotoxicity of methanolic extract of Sida cordata leaves. Int J Biol Pharm Res. 2014; 5(2):196-200.

26. Sakiyama Y, Sujaku T, Furuta A. A novel automated method for measuring the effect of analgesics on formalin-evoked licking behavior in rats. J Neurosci Methods. 2008; 167(2): 167175.

27. Islam MR, Uddin MN, Reza AMA, Rana MNU, Farhana K. In vivo evaluation of analgesic activity of methanolic extract of Laportea interrupea (L.) leaves. J Chem Pharm Res. 2014; 6(1): 552-556.

28. Khan H, Saeed M, Khan MA, Dar A, Khan I. The antinociceptive activity of Polygonatumverticillatum rhizomes in pain models. J Ethnopharmacol. 2010; 127(2): 521527.

29. Sani M, Zakaria Z, Balan T, Teh L, Salleh M. Antinociceptive activity of methanol extract of Muntingia calabura leaves and the mechanisms of action involved. Evid Based Complement Alternat Med. 2012; 2012.

30. Shibata M, Ohkubo T, Takahashi H, Inoki R.
Modified formalin test: characteristic biphasic pain response. Pain. 1989; 38(3): 347-352.

31. Arya D, Meena M, Grover N, Patni V. In vitro anti-inflammatory and anti-arthritic activity in methanolic extract of Cocculus hirsutus (L.) Diels. In vovo and In vitro. Int J harmaceut Sci Res. 2014; 5(5): 1957.

32. Shravan K, Kishore G, Siva K, Sindhu P. In vitro anti-inflammatory and anti-arthritic activity of leaves of Physalis angulata L. Int J Pharm Ind Res. 2011; 1(3):211-213.

33. Previtali E, Bucciarelli P, Passamonti SM, Martinelli I. Risk factors for venous and arterial thrombosis. Blood Transfusion. 2011; 9(2): 120.

34. Rathee $P$, Chaudhary $H$, Rathee $S$, Rathee D, Kumar V, Kohli K. Mechanism of action of flavonoids as anti-inflammatory agents: a review. Inflamm Allergy Drug Targets. 2009; 8(3): 229235.

35. Fowles RG, Mootoo BS, Ramsewak RS, Khan A. Toxicity-structure activity evaluation of limonoids from Swietenia species on Artemia salina. Pharm Biol. 2012; 50(2): 264-267.

36. Parra AL, Yhebra RS, Sardiñas IG, Buela LI. Comparative study of the assay of Artemia salina $\mathrm{L}$. and the estimate of the medium lethal dose (LD50 value) in mice, to determine oral acute toxicity of plant extracts. Phytomedicine. 2001; 8(5): 395-400. 